\title{
Entrepreneurial Characteristics of Women Entrepreneurs in Micro Enterprises
}

Dr. Uma Balakumar, Ramaiah Institute of Management, Bangalore, India. umab@msrim.org

Dr. Triveni P, Ramaiah Institute of Management, Bangalore, India. triveni@msrim.org

\begin{abstract}
Entrepreneurship is a big challenge which has all kinds of twists in it. The women who venture out in the entrepreneurial journey need to be ready for many challenges. This paper is aimed at assessing the entrepreneurial characteristics of women entrepreneurs in micro enterprises in Tiruchirappalli District of Tamil Nadu. The study aims at identifying the entrepreneurial characteristics of women entrepreneurs associated with Women Entrepreneurship Association of Tamil Nadu (WEAT).They were personally interacted and result shows that the women between the age group of 3544 years are at a prime age for business and shown tremendous aggression in various segments of entrepreneurial characteristics. The middle-aged women have understandably expressed focus on profit and growth. The study concludes that the women from the manufacturing sector have expressed a high degree of entrepreneurial characteristics than those from the service sectors.
\end{abstract}

Key Words: Entrepreneurial Characteristics, Risk Taking Behavior, Women Entrepreneurs.

\section{Introduction}

Women play a vital and crucial role in the society.The women population throughout the world is almost equal as that of the men, though there must be a small percentage of variation and yet there is still a substantial entrepreneurial capacity that is untapped. Entrepreneurship is facilitating the women to raise their socio economic standards, creating job opportunities that are providing and is enabling them to assert themselves throughout the world. This is emerging as a platform for lucrative employment in all over the world.A projected 48 million female entrepreneurs and 64 million female business owners currently employ one or more people in their businesses. In addition, these women plan to grow their businesses. A predicted seven million female entrepreneurs and five million female established business owners plan to grow their businesses by at least six employees over the next five years.

The rate of women employment has seen a significant growth on comparison with average employment rate with an increase of 2.7 points in 3 years. This has been proclaimed during the first annual report on developments towards gender equality. This is a noteworthy as the development has just not been a quantitative but also a qualitative increase both in employed as well as self-employed categories. Women generally create smaller but relatively viable business enterprises. Women tend to play an important role and entrepreneurship is considered not only as renaissance but a revolution worldwide. Women basically possess a natural talent when it comes to innovation, creating new ideas or product. They also have displayed the dynamic capacities in terms of adapting the changes taking place in the environment. They act as an economic agent by formatting and creation of an enterprise, continued with the production of goods and services for the society. 


\section{Entrepreneurship and Startups}

\section{Women Entrepreneurship}

The Global Entrepreneurship Monitor (GEM) concludes in its study that women entrepreneurs represent an important contributor to economic growth, especially in the countries with low or average incomes.Age, education, sources of capital, initial investment, size of business, type of training and earnings are determining factors of women entrepreneurship. It has a direct impact on the selfdependency, socio-economic status and eliminating of gender discrimination. Self-employment and income generating activities isdriving these women to earn more money for the family, independence, creating employment opportunities for themselves and unemployed and through this process contributing for the economic development. It is very essential to provide the requisite finance, create a general awareness and importance of the business they are intending for the economic growth. Their entrepreneurial services are majorly focused on the business that makes utilization of locally available resources, best usage of geographic conditions to name a few. In the process they create jobs for themselves and also provide more working opportunities to both men and women. It is very well agreed by the academicians and practitioners (i.e. Allen et al., 2007) that various researches have shown that women entrepreneurship is contributing to the innovations, creating new products, new market in all economies (i.e. Brush el al, 2006). This facilitates in poverty reduction (Yunus, 2007) and impact on local communities and surroundings. It is observed in the recent years that women are engaged in entrepreneurial activity have increased substantially. The statistics in 2010 show over 104 million of women in 59 countries accounting to 52 percent of the world's population and 84 percent of the global GDP, set up new businesses creating employment and different activities in labour markets (Kelly, Brush, Greene, and Litovsky, 2011). India is witnessing a significant growth in women entrepreneurship.

The women often engage in home based venture that enables them to attend both the domestic responsibilities and improve the financial conditions of their family. Realizing this various Government agencies, Banks, NGOs have come forward to assist them in terms of providing loans, managerial, and psychological assistance to start the enterprises.

\section{Operational definition of Entrepreneurial Characteristics}

The entrepreneurial characteristics of women considered in this study are: the purpose behind starting the business, need for achievement, confidence level, innovative behavior, utilizing opportunities, taking advantage of the locally available resources, risk taking behavior and setting clear goals for business.

\section{Characteristics of Women Entrepreneurs}

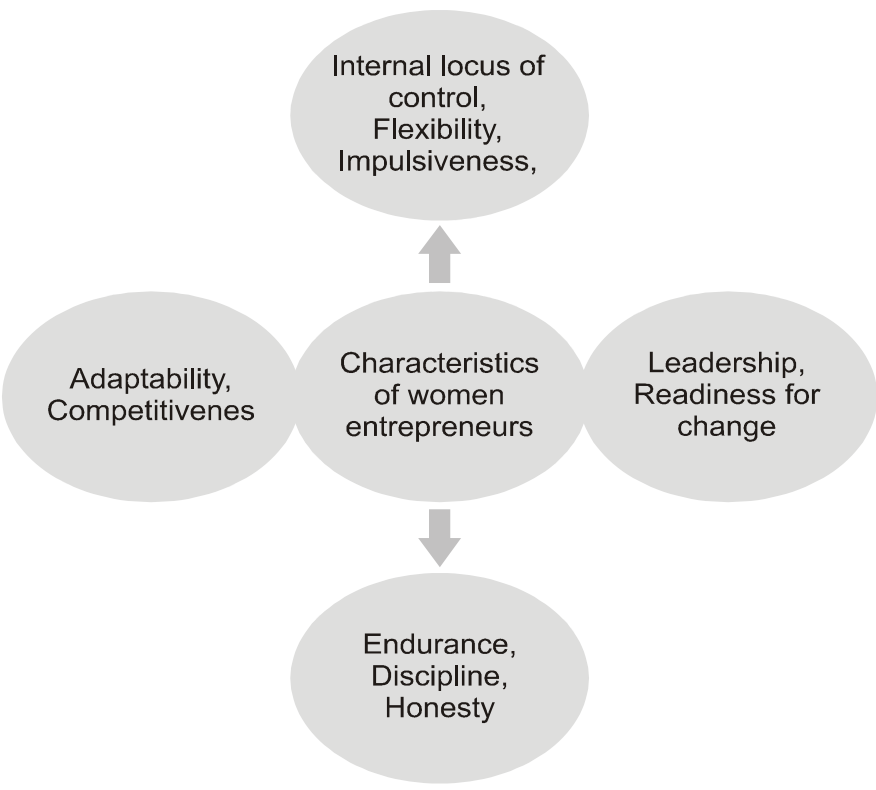

\section{Research Problem}

The study on women's entrepreneurship internationally conducted by author Susanne Jalbert (2000) has written that, the available literature mostly focuses on women's business ownership on entrepreneurial development in industrialized countries and less within developing countries. Very little information is available on the role of women 


\section{Entrepreneurship and Startups}

entrepreneurs in the global economy (R. Julie and Seiler, Danielle, (2001).

The researchershave formulated the research problem based on the following assumptions;

Firstly, there are numerous studies conducted worldwide on various aspects of women entrepreneurs' age, education, race, marital status, and problems faced. Studies have also been conducted on core business activities like growth rate of firms, sales volume, personal income and value added inferences. Though there are rich literature on women contributing visibility to their efforts, there are few studies conducted on the entrepreneurial characteristics of the women. Secondly,to study the entrepreneurial characteristics of the women entrepreneurs, and its influences in the business ventures, as there has not been much research undertaken on the entrepreneurial characteristics of the women in India especially in Tiruchirappalli district of Tamil Nadu and hence received lesser or inadequate academic attention.

\section{Objectives of the Study}

1. To identify the profile of women entrepreneurs in micro enterprises in Tiruchirappalli District of Tamil Nadu.

2. To identify the entrepreneurial characteristics of women entrepreneurs.

\section{Review of Literature}

The characteristics of men and women entrepreneurs differ in various important aspects. Hisrich, Micheal and Shepherd (2005) critically evaluating this, argues that differences in men and women entrepreneurs' characteristics are a result from the fact that both differ in terms of; reasons for starting an enterprise, types of business they run, method chosen for accessing finance, choice of business location, choice of labour force, educational background, age,business of the parents, position in the family, educational background, propensity to risks taking, structure of business, type of business ownership, sources of finance, type of marketing (Cited in Okafor,
Chinonye, 2009).GEM has defined innovation as the extent to which entrepreneurs offer products or services that are new to some or all customers, with additional consideration for the extent that no or few other businesses offer that same product. Women have exhibited change in their leadership qualities and are evident from the fact of assuming higher positions in the Organizations and fulfilling the tasks equal to the men employees.

The contribution of the women entrepreneurs plays an important role in the entrepreneurial economy of the nation. Though a bigger percentage is limited to medium and micro entrepreneur level of business, yet their contribution is very vital and essential. Their entrepreneurial services are majorly focused on the business that makes utilization of locally available resources, best usage of geographic conditions to name a few. In the process they create jobs for themselves and also provide more working opportunities to both men and women. In developing world women are in the front line of entrepreneurial activities like mobile canteens, flower vending, vegetable vending, beauty parlors, and manufacturing bakery products. Many women entrepreneurs in the developing or developed countries have become the breadwinners or the main source of earning for the family, as the contribution from the male members are meager. The sufficient earning of the women could also be cited as a reason for this. Women entrepreneurship is usually limited to microenterprises as well as small medium enterprises.

\section{Research Methodology}

A sample of 200 respondents was selected for a survey in Tiruchirappalli district of Tamil Nadu in Southern India. Structured questionnaire was used to collect the primary data from the various micro enterprises established in trade, agricultural production, engineering, manufacturing and service. All women entrepreneurs are into running these micro enterprises. 


\section{Entrepreneurship and Startups}

\section{Population of the study}

The universe of the study consists of 352 micro women entrepreneurs as per the record maintained at Women Entrepreneurship Association of Tamil Nadu (WEAT). The universe is stratified into different business category (28) i.e. (Food products, Engineering industries, Stalls, Garments manufacturing, Beauty parlors, Tailoring, Sanitary napkins, Areca nut plates, Kundan jewelry, Herbal products, Jute bags, Baniyan waste, Handicrafts, Cab driving, Leather gloves, Computer allied services, Banana fiber, Paper cup, Paper bag, Gem cutting, Catering, Array work, Telephone booth, Printing, Insurance, Event management, rendering Business Process Outsourcing services and others. From each business category women entrepreneurs were selected using the convenience sampling method proportionate to their total.

\section{Sampling Unit}

Sampling unit is the basic unit containing the elements of the population. The researcher has taken the women entrepreneurs of micro enterprises and are classified based on the nature of business. The researcher has selected 75.5 percent (151) of women from manufacturing industries and 24.5 percent (49) from service industries.

\section{Sampling method}

The sampling units were selected based on the convenience sampling under the non-probability sampling method. The data was collected from the respondents on account of being available in the business premises where the study was conducted.

\section{Research Instruments}

\section{Questionnaire}

The questionnaire represents a statistical form, prepared to collect the standardized data posed with the same set of questions to 200 respondents. The questionnaire was prepared meticulously after taking various factors into consideration that includes the formulation of research problem, objectives of the study, precision of the hypothesis, questions based on pilot study, series of questions-structured and open ended, sample size of the respondents, size and layout of the questionnaire. The questions used in the study represent variables that were designed, prepared and suitably validated prior to data collection and the feedback received from the pilot study was incorporated into the questionnaire.

The questionnaire was designed to be an SPSSfriendly one and the questions were coded so that the responses obtained could be quantified to obtain tangible results (Oppenheim, 1992). The IBM SPSS statistics (version 20.0) was used to conduct statistical analysis of the data obtained. The data analytic tool includes the descriptive statistics and the sampling research was achieved through personal interviews, a technique extensively used as the most complete and concise method of communicating with the public. This method was used because of its high credibility, despite the disadvantages of the great cost and the personal occupation (Pizam, 1994, Cited in lakovidou, Olga et al, 2009). The methodology consisted of qualitative and quantitative research.

\section{Data Analysis}

\section{Entrepreneurial Characteristics}

Entrepreneurial ventures are an area of career which is chosen by the people for various reasons and could be varied but one fact that binds them together with this venture practically is the finance and career. It is vital that the business is chosen appropriate to the capabilities, market demands, and financial stabilities, as any adversities results in the loss of business not only in terms of finance but also has a major impact on one's career. It is also equally important that this initiative is self-driven and not by compulsion or to avail benefits of any kind as this effort might not generate any competence in the entrepreneurs and ultimately leads to the failure. 
TABLE NO. 1

ENTREPRENEURIAL CHARACTERISTICS

\begin{tabular}{|c|c|c|c|}
\hline \multirow{2}{*}{$\begin{array}{l}\text { Entrepreneurial } \\
\text { Characteristics }\end{array}$} & \multicolumn{2}{|c|}{ Classified } & \multirow[t]{2}{*}{ Total } \\
\hline & Low & High & \\
\hline \multirow{2}{*}{$\begin{array}{l}\text { Principal purpose is } \\
\text { profit \& growth }\end{array}$} & 0 & 59 & 59 \\
\hline & - & $32.1 \%$ & $29.5 \%$ \\
\hline \multirow{2}{*}{$\begin{array}{l}\text { High need for } \\
\text { achievement }\end{array}$} & 0 & 38 & 38 \\
\hline & - & $20.7 \%$ & $19.0 \%$ \\
\hline \multirow{2}{*}{$\begin{array}{l}\text { High level of } \\
\text { confidence }\end{array}$} & 0 & 32 & 32 \\
\hline & - & $17.4 \%$ & $16.0 \%$ \\
\hline \multirow{2}{*}{ Innovative behavior } & 3 & 16 & 19 \\
\hline & $18.8 \%$ & $8.7 \%$ & $9.5 \%$ \\
\hline \multirow{2}{*}{$\begin{array}{l}\text { Opportunity-driven } \\
\text { (exploit opportunities } \\
\text { in rapidly changing } \\
\text { environment) }\end{array}$} & 0 & 13 & 13 \\
\hline & - & $7.1 \%$ & $6.5 \%$ \\
\hline \multirow[t]{2}{*}{ Risk taking behavior } & 0 & 12 & 12 \\
\hline & - & $6.5 \%$ & $6.0 \%$ \\
\hline \multirow{2}{*}{$\begin{array}{l}\text { Have a tremendous } \\
\text { amount of energy } \\
\text { and drive }\end{array}$} & 13 & 7 & 20 \\
\hline & $81.3 \%$ & $3.8 \%$ & $10.0 \%$ \\
\hline \multirow{2}{*}{$\begin{array}{l}\text { Set clear goals for } \\
\text { the business }\end{array}$} & 0 & 7 & 7 \\
\hline & - & $3.8 \%$ & $3.5 \%$ \\
\hline \multirow[t]{2}{*}{ Total } & 16 & 184 & 200 \\
\hline & $8 \%$ & $92 \%$ & $100 \%$ \\
\hline
\end{tabular}

Source: Primary Data.

Note: \% within Entrepreneurial Characteristics -

Classified

\section{ENTREPRENEURIAL CHARACTERISTICS}

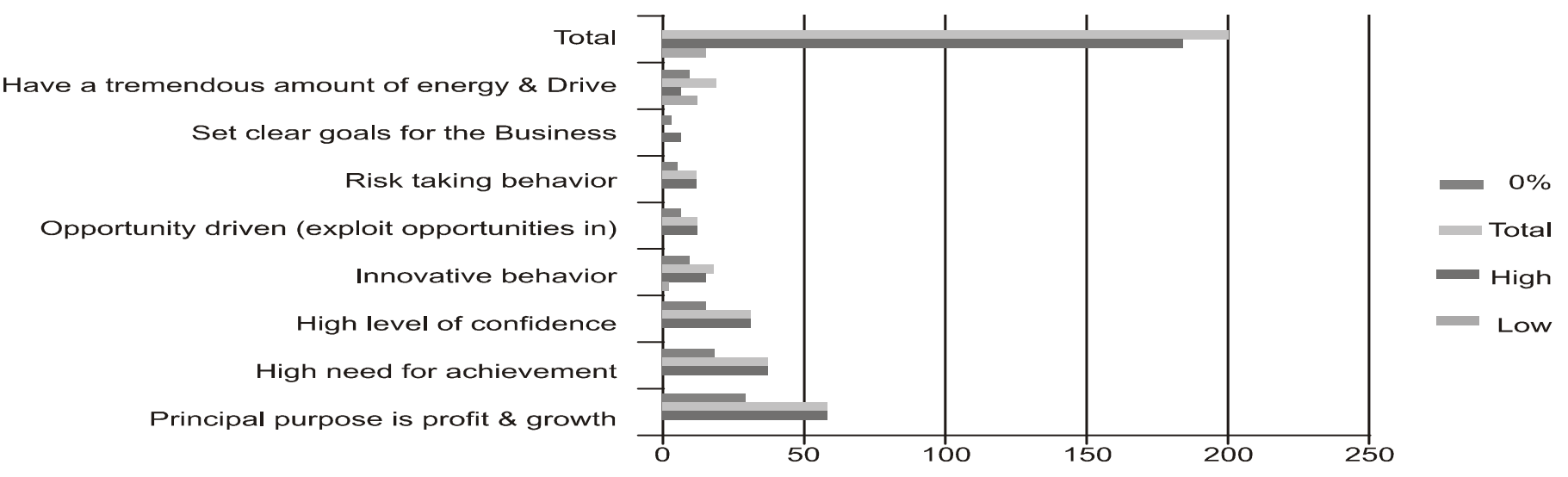

The study shows that the entrepreneurial characteristics of the women were found to be at a high of 92 percent whereas it is low at 8 percent. The results in the table have stated that financial needs of the family to have obligated them to choose this line of career and the main focus are the profit and growth. The financial condition of average women in the urban and rural is highly limited or a hand to mouth existence. Though the cost of basic amenities like food and shelter might be lesser when compared to the urban areas, the cost of living for other criteria's like education, health, transportation to name a few are in par with the urban counterparts. However, the source of income generated by the male members of the family alone might not be sufficient to addresses the essentials needs.

However, taking regular employment might not be a good alternative as the women are constrained with varied family conditions and requirements. Given the financial support from the Government and the NGOs these women feel that venturing into the business line of activities would be much lucrative than regular employment. The women would be able to choose the career of their interest and abilities and the researcher was interested to find out the entrepreneurial characteristic of the women that enabled them to take a decision in this venture. The reasons are varied from financial needs, need for achievement, confidence, innovative behavior, opportunity driven, risk taking behavior, self-drive and setting goals for business. 


\section{Innovative behavior}

Innovation in one of the form may be defined as "the ability of transforming an idea into a product or a service that generates values and converting it into money". In-order to be called as innovative the product or the service must be unique and deliver value to the customers and reasonably economic. It is found that the women in the urban and rural areas having good innovative qualities and abilities in converting the locally available resources into useful products. Unlike the women of yesteryears, the women these days are not introverted to bring out their hidden talent and convert them into money. This speaks of the women's growing confidence and selfsustainability attitude rather than dependence on the male members conventionally. This is a great source of development as far as the women in rural areas of the country that have been considered to low profiled when compared to their urban counterparts. However, the analysis shows the women entrepreneurs venturing into the business due to innovative abilities to be very much at the lower side. The results in the table could not be taken as evidence to write off the women in the urban and rural areas as many women still possess the ability to be innovative. Factors like lack of confidence, pessimistic attitude, insufficient support or encouragement from the family, family obligation to name a few suppresses the innovative skills of the women.

\section{Opportunity-driven (exploit opportunities in rapidly changing environment)}

The need to survive and achieve generates the interest in the people to lookout for opportunities. Opportunity driven entrepreneurship might be defined as a process of business venture to make best utilization of the existing opportunities in the environment. In a country like India opportunities are abundant, some are visible and others non-visible. It is the ability of the individual to identify the opportunities to the best of their abilities and in the process convert them into business models. The opportunities could be in the form of utilizing the locally available resources like banana fiber extraction from banana stem as Tiruchirappalli district is known for abundant banana cultivation, to utilize the person's natural talent, best utilization of the benefits and support by the Government to name a few. These women make best use of the opportunities mentioned above and become successful entrepreneurs. The self-driven attitude like person's innovative skills, natural talent, need to achieve, selfconfidence, self-sustainability, provide employment to fellow women, to name a few could also be considered as opportunities for the business ventures. These attributes of the women have expressed a good percentage as shown in the table.

\section{Risk taking behavior and Energy level of women entrepreneurs}

The risk taking behavior of the women has always been a low profile affair either in business or any other occupation. It is natural as the physiological and biological conditions of the women have always prevented them into getting into any of the fields that is considered as risky. Though the women are trying to break this barrier and be in par with the men in some areas where risk factor is high, the percentage is and will always be a negligible factor. Though venturing into business especially by itself is considered as a risk taking behavior in our society, the women have shown great progress and success. However, the risk taking abilities of the women to venture into business is not a factor that is much prevalent in the business arena, though few women have expressed this attitude for venturing into the business as indicated in the table.

\section{Age and Entrepreneurial Characteristics}

The analysis shows that various age-wise characteristics that have driven the women and irrespective of age, finance is the main reason that has led the women to the business arena. The women between the age group of 35-44 years are at a prime age for business and shown tremendous aggression in various segments of entrepreneurial characteristics. The middle-aged women have understandably expressed focus on the profit and 


\section{Entrepreneurship and Startups}

growth. It is during these years the best efforts are exercised onto the business activities with the main intent of earnings and growth. The age provides the women a good confidence and energy to think out of box, need to achieve, try innovations and expansion of the business. This provides a great boost to the dynamic qualities and imparts a tremendous amount of energy to drive other initiatives that even has a fair degree of risks. In the process they are able to visualize and set clear goals for their business. The women in the age group of lesser than 35 years have not shown much prominence to the profit and growth as this is the period of learning and establishing. Though the need to achieve, self-confidence, risk taking abilities is prevalent in the women, the inexperience has always put them in the back seat in comparison with the middle aged women. The entrepreneurs above 45 years are at an age where the women feel more content with their possession and this attitude lowers the progress to scale higher. Also the physical health of the Indian women above 45 years does not offer much support to the competent entrepreneurial characteristics.

\section{Education and Entrepreneurial Characteristics}

Education plays an important role in the lives of the people as it imparts a certain degree of knowledge, awareness, behavior and confidence than to the people without or less education. Educated women entrepreneurs definitely have an edge naturally, over the other women be it personal or professional as proved in the table. Though the women of all sections have expressed principal purpose of entrepreneurial activity is the finance generation and growth, the educated women have excelled in the areas of need for achievement, confidence level, the energy required to drive the enterprise, and innovation. However, the ability to assess the pros and cons prevents the women in risk taking characteristics. Though the entrepreneurial characteristic amongst the women with diploma or of lesser education have revealed similar entrepreneurial characteristics, the risk taking abilities of the women with HSC has been at a higher side.

\section{Family Business Background and Entrepreneurial Characteristics}

The study portrays an encouraging, though surprising results that could be an eye- opener for many women, as the entrepreneurial characters expressed by the women from non-business background to be higher than the women form business background. This could be justifiable as the women from non-business need to be more dynamic as they are in the process of establishing their business ventures as against the women who hail from an already established environment. As the need to earn is immediate with the women from non-business background due to various liabilities, the women have expressed the profit and growth much higher than the women from business background who might have already been established with lesser liabilities. The women from the non-business background have begun their career and hence the need for achievement that generates the self-driven characteristics, confidence level, innovative characteristics and risk taking capabilities is much higher than the women from business background.

\section{Nature of Business and Entrepreneurial Characteristics}

The study shows that the women from the manufacturing sectors have expressed a high degree of entrepreneurial characteristics than the service sectors. The scope to earn more and the growth rate in the manufacturing industries are always found to be higher. To sustain the high competition, the entrepreneur needs to leverage a high level of competence by being more innovative. In order to be innovative, need to achieve and the self-driven qualities of the women are required to be at its best and justified by the results in the table. As the manufacturing area is vast, with more opportunities to grow and expand, the women have from manufacturing industries have expressed higher entrepreneurial characteristics in exploring the opportunities than the women from service sectors where the scope to growth is much lesser. 


\section{Entrepreneurship and Startups}

\section{Community and Entrepreneurial Characteristics}

The community based discrimination is still an area of concern in India and more particularly with the women from rural sectors where the high community dominance is prevalent. However, the table shows different results wherein the women from backward or the lower section of the society have expressed the entrepreneurial characteristics much higher than the women of high community. The need to earn, achieve and self-driven characteristics by the women from lower sections of the society has been much higher. The results show that women of the lower section of the society making good utilization of the opportunities provided by the Government and scale up in the society so that the community discrimination will have a reduced effect. One of the reasons that could be attributed for this discrimination is the financial factor which the women from the lower sections are deprived. The confidence and the risk taking abilities of backward community women have also been on the higher side comparing to the women from forward community.

\section{Results and Findings}

- The study shows that the entrepreneurial characteristics of the women were found to be at a high of 92 percent whereas it is low at 8 percent.

- The analysis showsthat the women entrepreneurs are venturing into the business due to innovative abilities to be very much at the lower side.

- The risk taking abilities of the women to venture into business is not a factor that is much prevalent in the business arena, though few women have expressed this attitude for venturing into the business.

- The women between the age group of 35-44 years are at a prime age for business and show tremendous aggression in various segments of entrepreneurial characteristics. The middle-aged

\section{$M_{\text {ABBS }}$} 12

women have understandably expressed focus on the profit and growth.

- The entrepreneurial characteristic amongst the women with diploma or of lesser education have revealed similar entrepreneurial characteristics, the risk taking abilities of the women with HSC has been at a higher side.

- The entrepreneurial characters expressed by the women from non-business background to be higher than the women form business background.

- The study shows that the women from the manufacturing sectors have expressed a high degree of entrepreneurial characteristics than the service sectors.

\section{Conclusion}

The entrepreneurial concept is very well accepted, encouraged and is more receptive towards the women, as the world has understood the abilities and importance of the women, which would contribute greatly to counter the economic challenges. Though there has been a steep increase in the support, assistance by the Government, Non-Government, other financial institutions and the need for business ventures by the women, appropriate efforts by both sides to reach out to the other, could also see steep increase in the women entrepreneurship directly resulting in adding and strengthening the economy.

\section{Acknowledgement}

Note: First and foremost, we are indebted to the women who participated in our study. We are grateful for the assistance provided by the Women Entrepreneurs Association of Tamil Nadu, India.

\section{References}

1. Bertaux, Nancy and Crable, Elaine, "Learning about Women Economic Development, Entrepreneurship and the Environment in India: a case study, Journal of Developmental Entrepreneurship, Vol. 12, No. 4 ,467-478, (C) World Scientific Publishing Company, 2007. 


\section{Entrepreneurship and Startups}

2. Ibeh, Ena-Mary, "Factors Affecting Performance of Women Entrepreneurs", Journal of Women's Entrepreneurship 40 and Education 1-2 (2009) 39-50,2009.

3. Iakovidou, Olga et al. Women Entrepreneurs in the Greek Countryside: A Typology according to Motives and Business Characteristics. Journal of Developmental Entrepreneurship, Vol. 14, No. 2, 165-179, (C) World Scientific Publishing Company.

4. Lechman, Ewa and Okonowicz, Anna, "Are Women Important for Economic Development? an evidence on women's participation in labor market and their contribution to economic growth in 83 world countries", sGUT Faculty of Management and Economics, Working Paper Series A (Economics, Management, Statistics, No 13, June 2013.
5. Martins ,Susanaet al., "Barriers to entrepreneurship and business creation", Coordinator ADRIMAG Susana Martins, November 2004, European entrepreneurship cooperation, 2004.

6. Okafor, Chinonye. Motivational Patterns of Women Entrepreneurs in Small and Medium Scale Enterprises: A Case Study in South-West Nigeria. Thesis report, April, 2009.

7. Patgaonkar, S Madhavi.Entrepreneurship Development among Women in Shrirampur Taluka of Ahmednagar District. The IUP Journal of Entrepreneurship Development, 52 Vol. VII, Nos. 1 \& 2, 2010.

8. Welsh, Dianne and Dragusin, Mariana, "WomenEntrepreneurs: A Dynamic force of small business sector", femeile-antreprenor: 2006. 